Research Paper:

\title{
The Relationship Between Serum and Cerebrospinal Fluid Concentrations of Zinc in Febrile Seizure
}

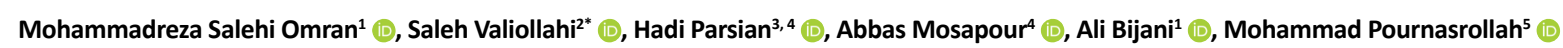

1. Non-Communicable Pediatric Diseases Research Center, Health Research Institute, Babol University of Medical Sciences, Babol, Iran.

2. Student Research Committee, Babol University of Medical Sciences, Babol, Iran.

3. Cellular and Molecular Biology Research Center, Health Research Institute, Babol University of Medical Sciences, Babol, Iran.

4. Department of Clinical Biochemistry, Babol University of Medical Sciences, Babol, Iran.

5. Clinical Research Development Unit of Amirkola Children's Hospital, Babol University of Medical Sciences, Babol, Iran

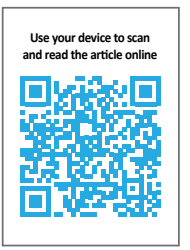

Chtation Salehi Omran M, Valiollahi S, Parsian H, Mosapour A, Bijani A, Pournasrollah M. The Relationship Between Serum and Cerebrospinal Fluid Concentrations of Zinc in Febrile Seizure. Journal of Pediatrics Review. 2020; 8(3):201-208. http://dx.doi. org/10.32598/jpr.8.3.696.2

doi $h$ http://dx.doi.org/10.32598/jpr.8.3.696.2

\section{(1) (3)}

Article info:

Received: 07 May 2019

First Revision: 17 May 2019

Accepted: 15 Feb 2020

Published: 01 July 2020

Keywords:

Febrile seizure, Seizures, Zinc, Epilepsy

\section{A B S T R A C T}

Background: Febrile Seizure (FS) which has different causes, is the most prevalent seizure type in children. Studies supported the role of Zinc (Zn) in FS.

Objectives: The present study aimed to evaluate the serum and Cerebrospinal Fluid (CSF) Zn level in children with FS.

Methods: This cross-sectional study was performed on 50 patients with FS aged 6 months- 6 years in Amirkola Children's Hospital in 2013-2014. The required demographic and clinical data were recorded employing a checklist. The serum and CSF Zn levels were determined using Atomic Absorption Spectrophotometry (AAS) method. The collected data were analyzed in SPSS using the Chi-squared teste, Independent Samples t-test, and Pearson correlation coefficient.

Results: The mean $\pm S D$ age of the explored patients was $12.78 \pm 8.38$ months and their mean $\pm S D$ serum $\mathrm{Zn}$ level was equal to $0.68 \pm 0.62 \mu \mathrm{g} / \mathrm{L}$. In total, $34(68 \%)$ of these 50 children presented $\mathrm{Zn}$ deficiency. The mean \pm SD CSF $\mathrm{Zn}$ level was measured as $33.29 \pm 11.84 \mu \mathrm{g} / \mathrm{L}$. Moreover, the mean \pm SD CSF $Z n$ level was equal to $37.71 \pm 10.82$ and $31.21 \pm 11.87$ in normal and abnormal serum $\mathrm{Zn}$ groups, respectively. In terms of mean CSF $\mathrm{Zn}$ level, there was no significant difference between the studied patients with healthy and decreased serum $\mathrm{Zn}$ level; $(P=0.07)$. No significant difference was found between the demographic/clinical characteristics of the investigated patients with $\mathrm{FS}$ and normal/abnormal serum levels of $\mathrm{Zn}(\mathrm{P}>0.05)$.

Conclusions: The obtained data revealed that a significant number of patients with FS had decreased serum Zn level; however, no association was detected between serum and CSF Zn concentration levels. 


\section{Introduction}

ebrile Seizures (FSs) are among the major causes of seizures in young kids. Almost $2 \%-4 \%$ of children aged $\leq$ five years suffer from FS; however, its incidence in some populations has been reported to be $15 \%$

(1-3). The pathophysiology of the FS is not well understood. Different mechanisms have been suggested for its pathology, including genetic predisposition, immunological factors, altered levels of Trace Minerals (TMs), low Gamma-Aminobutyric Acid (GABA) levels, and so on (4).

TMs importantly influence growth, structural tissue maintenance, and the Central Nervous System (CNS) development. The importance of TMs in the physiology of the CNS is well established in the literature; their concentration alternations in biological fluids were investigated in neurological diseases (5-7). Zinc (Zn), as one of the most crucial TMs in the body, significantly impacts numerous metalloenzymes, i.e., essential in the CNS function (8). The role of GABA is well-documented in previous studies. It works as a crucial inhibitory neurotransmitter in the pathophysiology of seizures. Decreased CSF concentration of GABA is associated with a group of seizure disorders, including febrile convulsions (9). Furthermore, $\mathrm{Zn}$, as a potent modulator of the glutaminergic synaptic transmission, regulates the activity of glutamic acid decarboxylase in the GABA synthesis process (10). Low levels of $\mathrm{Zn}$ have been detected in the serum and CSF of epileptic patients (11). Besides, experimental studies have suggested that fever (i.e., infections) may temporarily reduce serum $\mathrm{Zn}$ concentrations (12). Data from animal studies and preliminary clinical studies have suggested a possible role of cytokine network, like interleukin 1, influencing neuronal excitability. Accordingly, it may influence the pathogenesis of FS (13-15).

According to the particular circumstances in the CSF and the protective role of the blood-brain barrier, the concentrations of TMs in the CSF are lower but steadier than serum. Additionally, the CSF composition reflects the biological activities in the brain more closely than the blood (16). The comparison between serum and CSF $\mathrm{Zn}$ among patients with $\mathrm{FS}$ is available; however, data are controversial in this area. Therefore, the present study aimed to evaluate the relationship between serum and CSF levels of $\mathrm{Zn}$ in patients with FS.

\section{Methods}

This cross-sectional study was conducted in Amirkola Children's Hospital affiliated to Babol University of Medical Sciences in 2013-2014. Fifty consecutive children (using the sample size formula) who were admitted with the primary diagnosis of FS and aged 6 months to 6 years were selected as the study samples. They were selected by non-random and convenience sampling techniques. The study protocol was approved by the Institutional Research Review Board and Ethics Committee of Babol University of Medical Sciences. After explaining the study purposes, informed consent was obtained from the studied children's parents. Then, 1.5 cc peripheral venous blood samples were obtained and 1.5 cc CSF samples were collected by Lumbar Puncture performed in the lateral recumbent position with a stainless-steel needle. Next, the collected samples were transferred to the $-800 \mathrm{c}$ refrigerator. The CSF samples with signs of traumatic spinal tap were excluded at this stage. A checklist, including age, weight, medical and family history, relevant data, body temperature at the admission, seizure duration, and seizure etiology was completed for each patient.

The exclusion criteria of the present study were children with cerebral palsy, metabolic disorders affecting CNS, the anatomical and structural malformation of CNS, neurodegenerative disorders, acute meningitis, previous $\mathrm{Zn}$ supplementation, and serum electrolyte disorders detected in biochemistry. In addition, to omit potential confounder effects, we initially ruled out these conditions; chronic diseases, inadequate absorption, bowel disease, alcohol intake, and histories of radiation therapy and surgery. For the Determination of $\mathrm{Zn}$ levels of serum and CSF by atomic absorption spectrophotometer, we followed the below procedure.

Samples: After collecting blood and CSF samples for measuring $\mathrm{Zn}$ level in all children, blood samples were centrifuged to remove cells (3000-4000 rpm for $10 \mathrm{~min}$ at $4^{\circ} \mathrm{C}$ ), and the supernatants were transferred to new polystyrene tubes. The samples were stored at $-80^{\circ} \mathrm{C}$ until the final analysis. The serum and CSF levels of $\mathrm{Zn}$ were assessed using flame and graphite furnace Atomic Absorption Spectrometry (AAS) method, respectively (PG-990, china). The normal range of $\mathrm{Zn}$ in serum was considered as 0.7-1.2 micg/L; however, constant value in CSF was not clear in resources.

Reagents and instrument: A stock standard solution of $\mathrm{Zn}$ at a concentration of $1000 \mathrm{mg} / \mathrm{l}(\mathrm{ppm})$ was prepared in a solution, containing $0.5 \mathrm{~mol} \mathrm{HNO}$ (ultrapure), sup- 
plied by Merck. The calibration curve was developed using standard solutions. PG990 atomic absorption spectrophotometry equipped with deuterium background correction, HGA graphite furnace attachment, and $\mathrm{Zn}$ hollow-cathode lamps as the radiation source, were implemented for analysis. The operating parameters were set as recommended by the manufacturer.

Flame Procedure for analysis of $\mathrm{Zn}$ in serum: $\mathrm{Zn}$ levels in the serum were evaluated by flame atomic absorption spectroscopy. In this method, working standard solutions were used. Analysis of each sample was conducted three times with the integration time of $3 \mathrm{~s}$. This measure helped us to obtain a Relatively Standard Deviation (RSD) of $\leq 5 \%$ within the calibration range. Zn concentrations were determined with a deuterium background correction. Working standard solutions for Zn were 2.50, 1.25, 0.625, 0.312, and 0.156 ppm, prepared from the stock standard of $1000 \mathrm{mg} / \mathrm{l}$, obtained from Merck. A linear calibration was obtained from the working standard $(R=0.996)$. All serum samples were diluted 3 times with distilled water, and the concentration of $\mathrm{Zn}$ was delineated in the diluted samples. The analytical characteristics of $\mathrm{Zn}$ are listed in Table 1.

Furnace graphite for analysis of $\mathrm{Zn}$ levels in CSF: For the quantification of $\mathrm{Zn}$ levels in CSF, a 4-point calibration curve of $\mathrm{Zn}$ was applied in the concentration range of $0-30(0,5,10,30) \mu \mathrm{g} / \mathrm{L}$ (calibration equation, $\mathrm{R}=0.996)$. The samples and standards were dried for $20 \mathrm{~s}$ at $120 \mathrm{C}$, charred (ashed) for $20 \mathrm{~s}$ at $300 \mathrm{C}$, and atomized for $4 \mathrm{~s}$ at $1300 \mathrm{C}$. The $\mathrm{Zn}$ levels of CSF were evaluated according to a standard curve. Furnace temperature settings are represented in tables 2 and 3.

Statistical analysis was performed using SPSS. Chisquared test and Independent Samples t-test was used to compare qualitative and quantitative variables between the study groups. Pearson correlation coefficient was applied to assess the correlation between the changes in serum and CSF levels of $\mathrm{Zn}$. $\mathrm{P}<0.05$ was considered as the significance level.

\section{Results}

In total, 50 (28 male [56\%] and 22 female [44\%]) children with FC met the research inclusion criteria and were entered into the present study. The Mean \pm SD age of the study participants was $12.78 \pm 8.38$ months; age range: 6-48 months. The Mean \pm SD birth weight and latest weight of study participants were $3.36 \pm 0.82$ and $9.31 \pm 1.72 \mathrm{~kg}$, respectively. Respiratory infections were the most frequent cause of fever in them (Figure 1).

Table 1. Hollow-cathode lamp conditions and flame conditions for FAAS

\begin{tabular}{cccccccc}
\hline Element & $\begin{array}{c}\text { Wavelengths } \\
(\mathrm{nm})\end{array}$ & $\begin{array}{c}\text { Lamp Current } \\
(\mathrm{mA})\end{array}$ & $\begin{array}{c}\text { Relativity (R) } \\
\text { of STD }\end{array}$ & $\begin{array}{c}\text { Detection Limit } \\
(\mathbf{m g} / \mathbf{l})\end{array}$ & \multicolumn{2}{c}{ Flow Rate of Flame Gases (I/min) } \\
\cline { 7 - 8 } & 213.9 & 5 & 0.996 & 0.003 & & Air & Acetylene \\
\hline $\mathrm{Zn}$ & & & & & & & Journal of Pediatrics Review \\
\hline
\end{tabular}

Table 2. Instrumental parameters for determining $\mathrm{Zn}$ by graphite furnace AAS

\begin{tabular}{ccccccccc}
\hline Zn & Wavelength & $\begin{array}{c}\text { Source } \\
\text { Lamp }\end{array}$ & $\begin{array}{c}\text { Slit } \\
\text { Width }\end{array}$ & $\begin{array}{c}\text { Background } \\
\text { Correction }\end{array}$ & $\begin{array}{c}\text { Measurement } \\
\text { Mode }\end{array}$ & $\begin{array}{c}\text { Calibration } \\
\text { Algorithm }\end{array}$ & $\begin{array}{c}\text { Integration } \\
\text { Time }\end{array}$ & $\begin{array}{c}\text { Sample } \\
\text { Volume }\end{array}$ \\
\hline 213.90nm & $\begin{array}{c}\text { HCL-5.1 } \\
\mathrm{ma}\end{array}$ & $2.0 \mathrm{~nm}$ & $\begin{array}{c}\text { Longitudinal } \\
\text { deuterium }\end{array}$ & Peak area & $\begin{array}{c}\text { Linear through } \\
\text { zero }\end{array}$ & $4 \mathrm{sec}$ & $10 \mu \mathrm{l}$ \\
\hline & & & & Journal of Pediatrics Review
\end{tabular}

Table 3. Graphite furnace temperatures for various cycles in an optimized method for $\mathrm{Zn}$

\begin{tabular}{ccccc}
\hline Stages & Temp $\left({ }^{\circ} \mathrm{C}\right)$ & Ramp(S) & Hold(S) & 10 \\
\hline Drying & 120 & 10 & 10 & 300 \\
Ashing & 300 & 10 & 4 & 0 \\
Atomization & 1300 & 0 & 2 & 300 \\
Clean up & 1600 & 1 & 300 \\
\hline
\end{tabular}

Journal of Pediatrics Review 


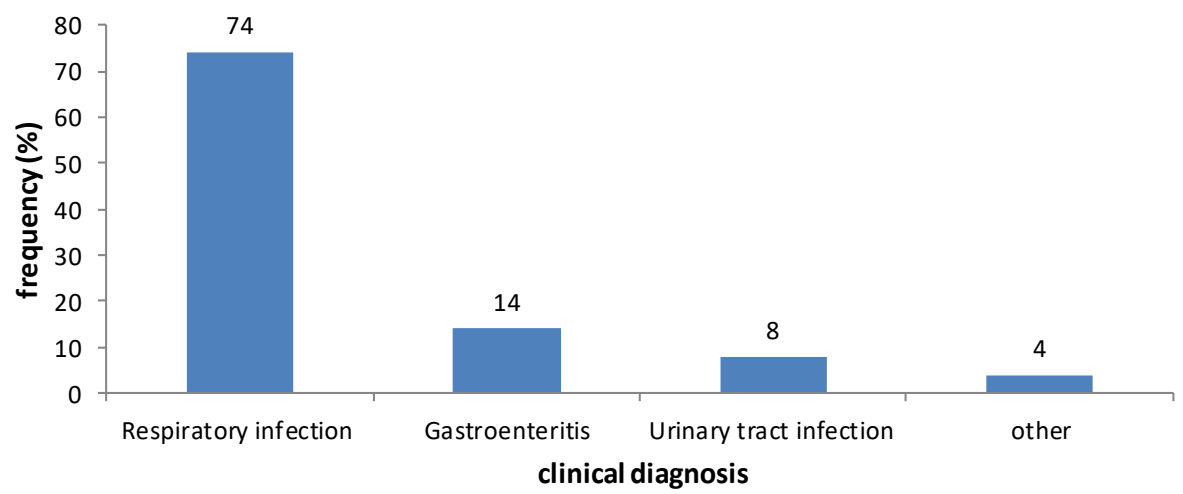

Figure 1. Frequency of the clinical diagnosis of the studied patients with FC

Journal of Pediatrics Review

The mean \pm SD serum $\mathrm{Zn}$ level with the minimum and maximum serum levels of 0.13 and $3.40 \mu \mathrm{g} / \mathrm{L}$, respectively, was equal to $0.68 \pm 0.62 \mu \mathrm{g} / \mathrm{L}$. Of these 50 children, 34 (68\%) patients presented $\mathrm{Zn}$ deficiency in FS (serum $\mathrm{Zn}$ level $<0.7 \mu \mathrm{g} / \mathrm{L}$ ). The mean \pm SD CSF $\mathrm{Zn}$ level with the minimum and maximum CSF levels of 14.33 and $54.48 \mu \mathrm{g} / \mathrm{L}$, respectively, were measured as 33.29 $11.84 \mu \mathrm{g} / \mathrm{L}$. As per Figure 2, there was no association between the serum and CSF levels of $\mathrm{Zn}$ in the investigated patients with $\mathrm{FC}(\mathrm{r}=0.173, \mathrm{P}=0.23)$.

In addition, the Mean \pm SD CSF $Z n$ levels in the normal and abnormal serum $\mathrm{Zn}$ groups were $37.71 \pm 10.82$ and $31.21 \pm 11.87$, respectively. Although the mean CSF level was lower in patients with decreased serum $\mathrm{Zn}$, there was no significant difference in the mean CSF Zn level in patients with normal and decreased levels of serum $\mathrm{Zn}(\mathrm{P}=0.07)$. As indicated in Table 4, no significant difference was found in the demographic/clinical characteris- tics of the studied patients with FC and normal/abnormal serum levels of $Z n(P>0.05)$.

\section{Discussion}

According to our findings, the mean \pm SD serum $\mathrm{Zn}$ level was obtained as $0.68 \pm 0.62 \mu \mathrm{g} / \mathrm{L}$ and the mean $\pm S D$ CSF $\mathrm{Zn}$ level was equal to $33.29 \pm 11.84 \mu \mathrm{g} / \mathrm{L}$. Although $68 \%$ of the studied patients with FS presented abnormal levels of serum Zn, no correlation was found in $\mathrm{Zn}$ levels between serum and CSF.

Ehsanipour et al. revealed that children with FS had significantly lower serum Zn levels, compared to their counterparts with convulsion and those with fever but without convulsion (17). This report was consistent with other studies in Korea (18), Indonesia (19), and Iran (20, 21). Zn seems to be a predicting factor for FS; accordingly, a low level of this element may be considered as a contributing factor for this disease among children (22).

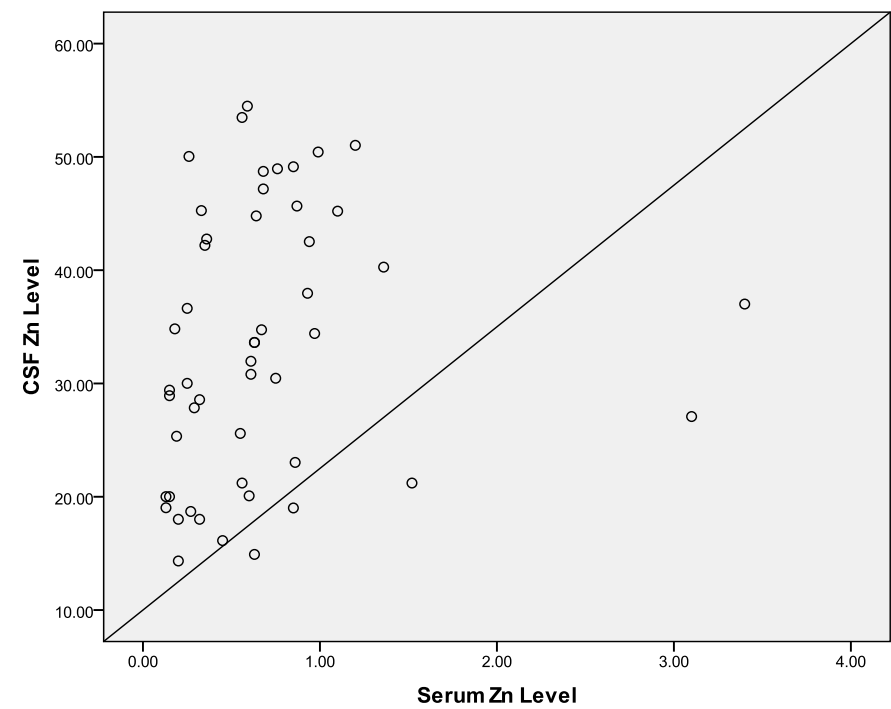

Figure 2. The relationship between the serum and CSF levels of $\mathrm{Zn}$ in the explored patients with FC 
Table 4. The demographic and clinical findings of the study participants

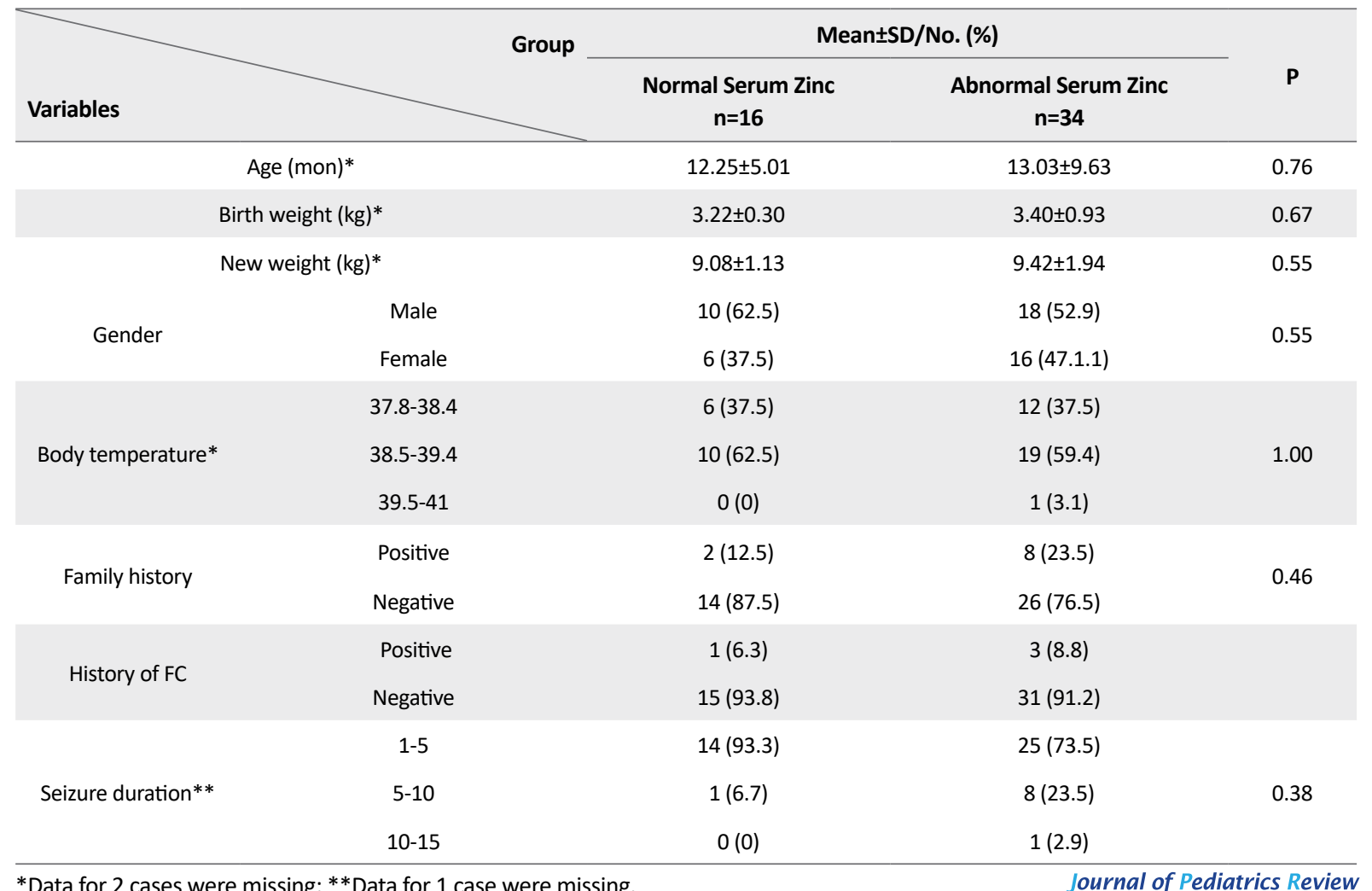

However, in a study on 45 children with FS in Iran, their Mean $\pm S D$ serum $Z n$ level was obtained a $184.04 \pm 65.5$ $\mu \mathrm{g} / \mathrm{dL}$, and their Mean \pm SD CSF $\mathrm{Zn}$ level was equal to $87.06 \pm 28.2 \mu \mathrm{g} / \mathrm{dL}$. Besides, no clear abnormality was observed in serum and CSF $\mathrm{Zn}$ of the study samples (23). Cho et al., in Korea, compared febrile convulsive patients with healthy children. As a result, no significant differences were observed in serum $\mathrm{Zn}$ concentration of the studied subjects (24).

Studies that evaluated $\mathrm{Zn}$ levels in both serum and CSF are scarce. Mollah et al. investigated the $\mathrm{Zn}$ concentration changes in serum and CSF among the children with FS, compared to their matched Non-Seizure Febrile (NSF) peers. They concluded that serum and CSF Zn simultaneously decreased in children with $\mathrm{FS}$, compared to their matched NSF children (25); i.e., inconsistent with the study conducted in Turkey (26), that presented a linear relationship between serum and CSF $\mathrm{Zn}$. This finding is inconsistent with those of ours and Mollah et al.'s study.

It is assumed that blood metal levels have no or limited impact on the levels of metals in the CSF. This is because the trace element environment of the brain is controlled through the blood-brain-barrier. Generally, the concentrations of the trace elements in the blood are considerably higher than their respective concentrations in the
CSF (16). Regional changes in CSF constituents could reflect local cerebral pathology and might not be detected by lumbar spinal fluid analysis. Therefore, for trace elements, the analysis of lumbar CSF concentrations and blood/CSF ratios are complex, and the expected correlations cannot be generally found (6). In the mouse model and in vitro studies, the mechanism underlying the role of $\mathrm{Zn}$ levels has been examined in seizures. Various studies have demonstrated that $Z n$ modulates specific GABA receptors, and this mechanism could inhibit the seizure. Nevertheless, despite some disagreement, human studies revealed that the FS group presented lower Zn levels, compared to the controls with simple fever, (18).

The limitations of the present study were as follows: a matched control group could not be recruited due to the exposure of the control group to the risks of unnecessary lumbar puncture; all children received some medications, such as antibiotics and antipyretic agents before and or after admission to the hospital. Such interventions could have affected the measurements of serum or possible CSF levels of Zn.

Remarkably, the present study patients had seizures despite high levels of $\mathrm{Zn}$ in their serum or CSF. There exist doubts about the role of $\mathrm{Zn}$ in FS and its preventive use in all geographical areas. Further studies with large 
sample sizes and different control groups in various geographical areas are recommended. Such investigations could help to support the existing hypothesis that low serum and CSF Zn play major roles in FS.

\section{Conclusion}

The results of the study suggested that in the children with FS, serum zinc level was significantly decreased. No association was identified between serum and CSF zinc concentration levels.

\section{Ethical Considerations}

\section{Compliance with ethical guidelines}

All ethical principles are considered in this article. The participants were informed about the purpose of the research and its implementation stages; they were also assured about the confidentiality of their information; moreover, they were free to leave the study whenever they wished, and if desired, the research results would be available to them.

\section{Funding}

This study was supported by a research grant and residency thesis of Dr. Saleh Valiollahi from the Non-Communicable Pediatric Diseases Research Center of Babol University of Medical Sciences (Grant No.: 9337715).

\section{Authors' contributions}

All authors were equally contributed in preparing this article.

\section{Conflicts of interest}

The authors declared no conflicts of interest.

\section{Acknowledgements}

We are grateful to the Clinical Research Development Committee of Amirkola Children's Hospital, Health Research Institute, Non-Communicable Pediatric Diseases Research Center of Babol University of Medical Sciences, and Mrs. Faeze Aghajanpour for their contribution to this study. The authors also would like to appreciate all personnel of Amirkola Children's Hospital for their contribution to this study.

\section{References}

1. Berg AT, Jallon P, Preux PM. The epidemiology of seizure disorders in infancy and childhood: Definitions and classifications. Handbook of Clinical Neurology. 2013; 111:391-8. [DOI:10.1016/B978-0-444-52891-9.00043-9] [PMID]

2. Hauser WA. The prevalence and incidence of convulsive disorders in children. Epilepsia. 1994; 35:S1-6. [DOI:10.1111/j.1528-1157.1994.tb05932.x] [PMID]

3. Patterson JL, Carapetian SA, Hageman JR, Kelley KR. Febrile seizures. Pediatric Annals. 2013; 42(12):249-54 [DOI:10.3928/00904481-20131122-09] [PMID]

4. Pavlidou E, Hagel C, Panteliadis C. Febrile seizures: recent developments and unanswered questions. Child's Nervous System. 2013; 29(11):2011-7. [DOI:10.1007/s00381-0132224-3] [PMID]

5. Gerhardsson L, Lundh T, Minthon L, Londos E. Metal concentrations in plasma and cerebrospinal fluid in patients with Alzheimer's disease. Dementia and Geriatric Cognitive Disorders. 2008; 25(6):508-15. [DOI:10.1159/000129365] [PMID]

6. Bogden JD, Troiano RA, Joselow MM. Copper, zinc, magnesium, and calcium in plasma and cerebrospinal fluid of patients with neurological diseases. Clinical Chemistry. 1977 23(3):485-9. [DOI:10.1093/clinchem/23.3.485] [PMID]

7. Amiri M, Farzin L, Moassesi ME, Sajadi F. Serum trace element levels in febrile convulsion. Biological Trace Element Research. 2010; 135(1-3):38-44. [DOI:10.1007/s12011009-8487-6] [PMID]

8. Kumar S, Kumar V, Mittal R, Jain D. Trace elemental analysis in epileptic children. Open Journal of Applied Sciences. 2013; 3:449-76. [DOI:10.4236/ojapps.2013.38056]

9. Garty BZ, Olomucki R, Lerman-Sagie T, Nitzan M. Cerebrospinal fluid zinc concentrations in febrile convulsions. Archives of Disease in Childhood. 1995; 73(4):338-41. [DOI:10.1136/adc.73.4.338] [PMID] [PMCID]

10. Frederickson CJ, Giblin L, Krezel A, McAdoo DJ, Mueller RN, Zeng $\mathrm{Y}$, et al. Concentrations of extracellular free zinc (pZn)e in the central nervous system during simple anesthetization, ischemia and reperfusion. Experimental Neurology. 2006; 198(2):285-93. [DOI:10.1016/j.expneurol.2005.08.030] [PMID]

11. Barbeau A, Donaldson J. Zinc, taurine, and epilepsy. JAMA Neurology. 1974; 30(1):52-8. [DOI:10.1001/archneur.1974.00490310054009] [PMID]

12. Izumi Y, Ishii K, Akiba K, Hayashi T. Hypozincemia during fever may trigger febrile convulsion. Medical Hypotheses. 1990; 32(1):77-80. [DOI:10.1016/0306-9877(90)90073-N]

13. Van Zeijl JH, Mullaart RA, Galama JM. The pathogenesis of febrile seizures: Is there a role for specific infections? Reviews in Medical Virology. 2002; 12(2):93-106. [DOI:10.1002/rmv.346] [PMID] 
14. Virta M, Hurme M, Helminen M. Increased plasma levels of pro- and anti-inflammatory cytokines in patients with febrile seizures. Epilepsia. 2002; 43(8):920-3. [DOI:10.1046/ j.1528-1157.2002.02002.x] [PMID]

15. Waruiru C, Appleton R. Febrile seizures: An update. Archives of Disease Childhood. 2004; 89(8):751-6. [DOI:10.1136/ adc.2003.028449] [PMID] [PMCID]

16. Melo TM, Larsen C, White LR, Aasly J, Sjobakk TE, Flaten $T P$, et al. Manganese, copper, and zinc in cerebrospinal fluid from patients with multiple sclerosis. Biological Trace Element Research. 2003; 93(1-3):1-8. [DOI:10.1385/ BTER:93:1-3:1]

17. Ehsanipour F, Talebitaher M, Harandi NV, Kani K. Serum Zinc Level in Children with Febrile Convulsion and its Comparison with that of Control Group. Iranian Journal of Pediatrics. 2009; 19(1):65-8.

18. Lee J-H, Jeong Hyun Kim. Comparison of serum zinc levels measured by inductively coupled plasma mass spectrometry in preschool children with febrile and afebrile seizures. Annals of Laboratory Medicine. 2012; 32:190-3. [DOI:10.3343/alm.2012.32.3.190] [PMID] [PMCID]

19. Margaretha L, Masloman N. Correlation between serum zinc level and simple febrile seizure in children. Paediatrica Indonesiana. 2010; 50(6):326-30. [DOI:10.1111/j.15264610.2009.01539.x] [PMID]

20. Salehiomran MR, Mahzari M. Zinc Status in Febrile Seizure: A case-control study. Iranian Journal of Child Neurology. 2013; 7(4):20-3.

21. Mahyar A, Pahlavan A, Varasteh-Nejad A. Serum zinc level in children with febrile seizure. Acta Medica Iranica. 2008; 46(6):477-80.

22. Nasehi M, Sakhaei R, Moosazadeh M, Aliramzany M. Comparison of serum zinc levels among children with simple febrile seizure and control group: A systematic review. Iranian Journal of Child Neurology. 2015; 9(1):17-24.

23. Sadeghzadeh M, Nabi S, Khoshnevisasl P, Mousavinasab N. The correlation between cerebrospinal fluid and serum zinc and calcium in children with febrile seizure. Journal of Comprehensive Pediatrics. 2013; 3(5):179-83. [DOI:10.17795/compreped-12133]

24. Cho W, Son B, Kim S. Levels of Sodium and Zinc Concentration in Febrile Convulsion. Journal of the Korean Child Neurology Society. 1999; 7(2):214-19.

25. Mollah MA, Rakshit SC, Anwar KS, Arslan MI, Saha N, Ahmed $\mathrm{S}$, et al. Zinc concentration in serum and cerebrospinal fluid simultaneously decrease in children with febrile seizure: Findings from a prospective study in Bangladesh. Acta Paediatrica. 2008; 97(12):1707-11. [DOI:10.1111/ j.1651-2227.2008.01001.x] [PMID]

26. Burhanoglu M, Tutuncuoglu S, Coker C, Tekgul H, Ozgur T. Hypozincaemia in febrile convulsion. European Jour- nal of Pediatrics. 1996; 155(6):498-501. [DOI:10.1007/ BF01955189] [PMID] 
This Page Intentionally Left Blank 